\title{
Acute Myeloid Leukaemia with Giant Inclusion: Pseudo-Che'Diak-Higashi Anomaly
}

\section{Dev İnklüzyonlu Akut Miyeloid Losemi: Pseudo-Che’'Diak-Higashi Anomalisi}

\section{Dear editor,}

A 52-year-old female patient who was admitted to our clinic with fever $\left(39^{\circ} \mathrm{C}\right)$ since for 7 days. She had pale appearance. Her blood parameters were as follows: leukocyte count $323 \times 10^{9} / \mathrm{L}$, hemoglobin $6 \mathrm{~g} / \mathrm{dL}$, hematocrit $19 \%$, and platelet count $11 \times 10^{9} / \mathrm{L}$. There were blastic cells (almost all of the cells) on peripheral smear and bone barrow aspiration. Acute myeloid leukemia (AML) (minimally differentiated according to World Health Organization classification, AML-M1 according to French-American-British classification) was diagnosed after bone marrow biopsy and flow cytometry. Blastic cells containing pseudo-Che'diak-Higashi inclusions were observed on peripheral smear and bone barrow aspiration (Figure 1). The inclusions might be the merger of primary granules.

In the literature, cases with pseudo-Che'diak-Higashi inclusions were reported rarely. This inclusions can be seen in AML or myelodysplastic syndrome (MDS) (refractory anaemia with excess blasts) (1-4). Myeloperoxidase activity-Sudan black B staining is positive for this inclusions that is form of azurophilic (primary) granules and composed of micro-structures like Auer bodies (2-5). Althought the clinical significance is unclear fort he inclusions, it is important to be similar of Auer rods.

Our aim is to emphasize the pseudo-Che'diak-Higashi inclusions that might be seen in patients with MDS or AML.

Informed Consent: Written informed consent was obtained from patient who participated in this study.

Peer-review: Externally peer-reviewed.

Author contributions: Concept - I.Y.; Design - I.Y.; Supervision - I.Y., G.S.; Resource - I.Y.; Materials - I.Y.; Data Collection\&/or Processing - I.Y., G.S.; Analysis\&/or Interpretation - I.Y.; Literature Search - I.Y., G.S.; Writing - I.Y.; Critical Reviews - I.Y. Conflict of Interest: No conflict of interest was declared by the authors.

Financial Disclosure: The authors declared that this study has received no financial support.

Hasta Onamı: Hasta onamı bu çalışmaya katılan hastadan alınmıştır. Hakem değerlendirmesi: Dış bağımsız.

Yazar Katkıları: Fikir - I.Y.; Tasarım - I.Y.; Denetleme - I.Y., G.S.; Malzemeler - I.Y.; Veri toplanması ve/veya işlemesi - I.Y., G.S.; Analiz ve/veya yorum - I.Y.; Literatür taraması - I.Y., G.S.; Yazıyı yazan - I.Y.; Eleştirel İnceleme - I.Y.

Çıkar Çatışması: Yazarlar çıkar çatışması bildirmemişlerdir.

Finansal Destek: Yazarlar bu çalışma için finansal destek almadıklarını beyan etmişlerdir.

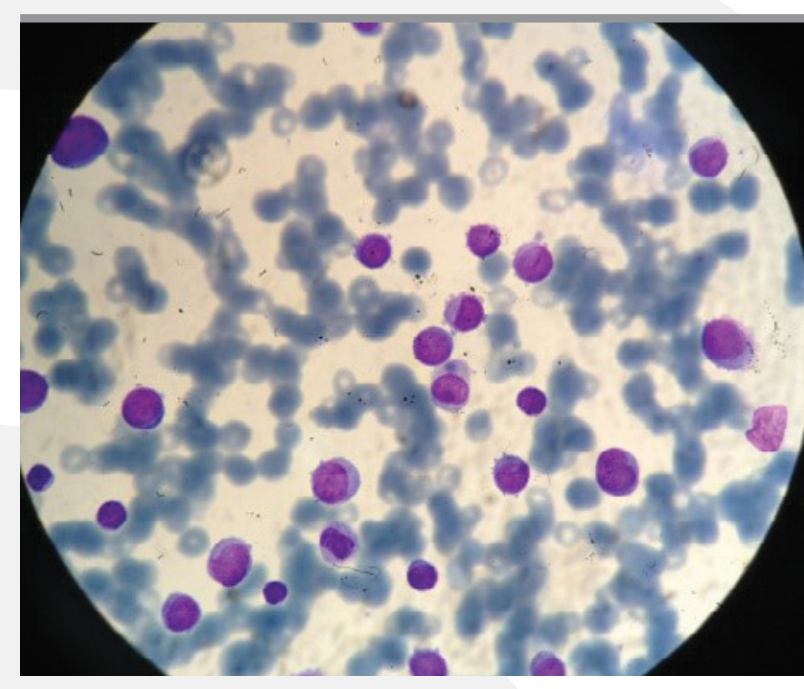

Figure 1. Blastic cell containing pseudo-Che'diak-Higashi inclusion

Yazışma adresi / Correspondence to: Dr. Gokhan Sargin, Adnan Menderes University Medical School, Department of Rheumatology, Aydın, Turkey Tel. / Phone: +90 5555952865 e.posta / e.mail: gokhan_sargin@hotmail.com Geliş Tarihi / Received: 30.08.2013 • Kabul Tarihi / Accepted: 23.06.2014 


\section{İrfan Yavaşoğlu', Gökhan Sargın²}

'Adnan Menderes University Medical School, Department of Hematology, Aydın, Turkey ${ }^{2}$ Adnan Menderes University Medical School, Department of Rheumatology, Aydın, Turkey

\section{Kaynaklar}

1. Abdulsalam AH, Sabeeh N, Bain BJ. Pseudo-Chédiak-Higashi inclusions together with Auer rods in acute myeloid leukemia. Am J Hematol 2011; 86: 602. [CrossRef]

2. Kakkar N, Das S, Joseph JM. Pseudo Chediak Higashi inclusions in a patient with acute myeloblastic leukemia. Indian J Cancer 2010; 47: 81-2. [CrossRef]
3. Mizushima W, Eguchi M, Sakakibara $\mathrm{H}$, et al. Electron microscopic cytochemistry of pseudo-Chediak-Higashi granules in 5 cases of AML. Rinsho Ketsueki 1990; 31: 799-806.

4. Tsai IM, Tsai CC, Ladd DJ. Pseudo-Chediak-higashi anomaly in chronic myelogenous leukemia with myelofibrosis. Am J Clin Pathol 1977; 67: 608-9.

5. Dittman WA, Kramer RJ, Bainton DF. Electron microscopic and peroxidase cytochemical analysis of pink pseudo-Chediak-Higashi granules in acute myelogenous leukemia. Cancer Res 1980; 40: 4473-81. 